\title{
Studi Kasus Proyek Co-Benefit Peningkatan Efisiensi Boiler Batubara di Industri Kertas
}

\author{
Syamsudin ${ }^{1 *}$, Katsushige Takami², Shoji Kita ${ }^{2}$, Mukharomah Nur Aini ${ }^{1}$, \\ Yusup Setiawan ${ }^{1}$, Reza Bastari Imran Wattimena ${ }^{1}$, Andri Taufick Rizaluddin ${ }^{1}$ \\ ${ }^{1}$ Balai Besar Pulp dan Kertas, Jl. Raya Dayeuhkolot No. 132, Bandung, Indonesia \\ ${ }^{2}$ Mitsubishi UFJ Research and Consulting Co., Ltd., Jepang \\ Diterima : 1 April 2020, Revisi akhir : 5 Juni 2020, Disetujui terbit : 30 Juni 2020 \\ Case Study of Co-Benefit Project Improvement of Coal Boiler Efficiency in \\ The Paper Industry
}

\begin{abstract}
Industrial rapid growth has caused greenhouse gas emissions problems. Co-benefit activities to improve the efficiency of coal boilers have been carried out in paper industry in the project of "Co-benefit Indonesia FY 2018" from the Japan Ministry of Environment aimed at identifying required steps to save energy and reduction of pollutant emission from the coal-fired industrial boilers and how to achieve it. Identification include analysis of boiler thermal efficiency, coal moisture content measurement, boiler feed water, blowdown water and condensate quality measurement, heat insulation examination, combustion air ratio management, and control of multiple boiler operations. Various heat losses have been analyzed and some recommendations have been proposed to be implemented by factory management to improve boiler efficiency. There are several issues that need to be addressed for energy conservation, namely: high water content coal utilization, high combustion air ratio, high conductivity feed water which causes high blowdown ratios, no insulation on relatively old production machines, and operational of several low efficiency boilers. The results of the co-benefit identification indicated that the potential for corrective action by adjusting the coal water content, improving the combustion air ratio, optimizing the blowdown ratio, recovering condensate water, installing insulation, and controlling multiple boilers theoretically can result coal consumption reduction of 16,445 tons/year or $48.63 \%$, and $\mathrm{CO}_{2}$ reduction of $19,589 \mathrm{tCO}_{2} /$ year with an estimated cost savings of Rp 12 billion/year.
\end{abstract}

Keywords: co-benefit, paper industry, boiler, coal, emission

Abstrak

Pertumbuhan industri yang pesat menyebabkan masalah emisi gas rumah kaca. Kegiatan co-benefit peningkatan efisiensi boiler batubara telah dilakukan di industri kertas dalam proyek "Co-benefit Indonesia Tahun 2018" dari Kementerian Lingkungan Hidup Jepang dengan tujuan melakukan identifikasi langkah-langkah yang terkait dengan konservasi energi dan penurunan polutan emisi boiler industri berbahan bakar batubara dan cara melakukannya. Identifikasi meliputi analisis efisiensi termal boiler, pengukuran kadar air batubara, pengukuran kualitas air umpan boiler, air blowdown, dan kondensat, pemeriksaan insulasi panas, pengaturan rasio udara pembakaran, dan pengendalian operasi multi boiler. Berbagai kehilangan panas dianalisis dan beberapa rekomendasi diberikan untuk implementasi di pabrik sehingga efisiensi boiler dapat ditingkatkan. Beberapa masalah yang perlu diperbaiki untuk konservasi energi meliputi penggunaan batubara dengan kadar air tinggi, rasio udara pembakaran tinggi, konduktivitas air umpan tinggi menyebabkan rasio blowdown tinggi, tidak dilakukan insulasi pada mesin produksi yang relatif tua, dan pengoperasian beberapa boiler dengan efisiensi rendah. Potensi perbaikan melalui penyesuaian kadar air batubara, perbaikan rasio udara pembakaran, optimalisasi rasio blowdown, pemulihan air kondensat, pemasangan insulasi, dan kontrol multi boiler secara teori menghasilkan reduksi konsumsi batubara 16.445 ton/tahun atau 48,63\%, dan reduksi $\mathrm{CO}_{2}$ sebesar $19.589 \mathrm{tCO}_{2} /$ tahun dengan estimasi penghematan biaya Rp 12 milyar/tahun.

Kata kunci: co-benefit, industri kertas, boiler, batubara, emisi 


\section{Pendahuluan}

Sejalan dengan pertumbuhan industri yang semakin pesat, maka perlu adanya upaya penanganan penurunan pencemaran udara (Wang et al., 2016; Song et al., 2015). Bertolak atas kondisi seperti ini, maka perlu promosi tindakan mereduksi gas rumah kaca dan pencemaran lingkungan dalam waktu yang bersamaan sebagai alat kebijakan penting berupa pendekatan co-benefit. Kementerian Lingkungan Hidup Jepang bekerjasama dengan Kementerian Lingkungan Hidup dan Kehutanan Indonesia telah melaksanakan proyek "Cobenefit Indonesia Tahun 2018" yang difokuskan pada boiler batubara di industri kertas. Pendekatan co-benefit dalam studi ini adalah penurunan gas efek rumah kaca (GRK) dan penurunan polutan emisi udara melaluiperbaikan pengoperasian boiler yang berfokus pada konservasi energi (MUFG, 2019). Konsumsi bahan bakar fosil berhubungan langsung dengan emisi $\mathrm{CO}_{2}$. Peraturan perlindungan lingkungan berupaya mengurangi emisi $\mathrm{CO}_{2}$ karena gas ini berkontribusi signifikan terhadap efek rumah kaca (Barma et al., 2017). Tindakan konservasi energi untuk mengurangi emisi $\mathrm{CO}_{2}$ juga mengurangi polutan udara lain seperti $\mathrm{SO}_{x}, \mathrm{NO}_{x}$ dan partikulat, membawa manfaat tambahan untuk kualitas udara (Yang and Teng, 2018). Pendekatan co-benefit dalam studi ini dapat menghasilkan tiga keluaran dalam waktu bersamaan karena penanggulangan yang dilakukan berkontribusi juga kepada penurunan biaya energi untuk industri.

Beberapa kontrol pembakaran dalam pengoperasian boiler batubara umumnya dilakukan secara otomatis untuk mendapatkan efisiensi pembakaran batubara, yaitu input batubara, laju alir udara pembakaran, konsentrasi oksigen dalam gas buang, tekanan steam, kualitas air umpan, dan laju dan kualitas air blowdown (MUFG, 2019). Berbagai kehilangan panas yang terjadi di dalam boiler dapat disebabkan antara lain oleh kehilangan panas karena karbon yang tidak terbakar, gas buang panas, kelembaban bahan bakar, uap air dari pembakaran hidrogen, pembentukan karbon monoksida, panas sensibel pada abu dasar, radiasi dan konveksi, dan blowdown (Gupta, Ghai and Jain, 2011). Identifikasi sumber utama pemborosan energi dan pemulihan energi yang terbuang diperlukan untuk menjalankan boiler pada efisiensi maksimum. Peningkatan efisiensi boiler akan membantu menghemat sejumlah besar bahan bakar fosil dan mengurangi emisi $\mathrm{CO}_{2}$, sehingga penting untuk memanfaatkan energi batubara secara efisien (Song et al., 2015). Studi ini bertujuan melakukan identifikasi langkah-langkah konservasi energi dan pengurangan emisi boiler industri berbahan bakar batubara dan cara melakukannya.

\section{Metode}

\section{Bahan}

Bahan bakar yang digunakan boiler berupa batubara lignit. Karakteristik batubara ditampilkan dalam Tabel 1.

\begin{abstract}
Alat
Boiler yang menjadi objek identifikasi hemat energi ini adalah jenis boiler unggun terfluidakan media pasir yang menggunakan bahan bakar batubara yang memiliki kapasitas 20 ton/jam dan 15 ton/jam di sebuah industri kertas. Peralatan yang digunakan dalam kegiatan ini meliputi flue gas analyzer merk Testo, conductivity meter merk Sato Tech, time lapse camera merk Brinno, thermography camera merk FLIR, dan thermochron type-SL merk KN Laboratories.
\end{abstract}

Tabel 1. Karakteristik Batubara

\begin{tabular}{lcc}
\hline Parameter & & Nilai \\
\hline Kadar air total (ar) & $\%$ & 25,8 \\
Kadar air (adb) & $\%$ & 11,9 \\
Abu (adb) & $\%$ & 9,8 \\
Zat terbang (adb) & $\%$ & 41,9 \\
Karbon padat (adb) & $\%$ & 36,4 \\
Sulfur (adb) & $\%$ & 0,86 \\
Karbon (adb) & $\%$ & 54,43 \\
Hidrogen (adb) & $\%$ & 5,41 \\
Nitrogen (adb) & $\%$ & 1,07 \\
Oksigen (by difference) (adb) & $\%$ & 28,43 \\
Gross calorific value (adb) & $\mathrm{kcal} / \mathrm{kg}$ & 5.232 \\
Harga batubara (ar) & $\mathrm{Rp} / \mathrm{kg}$ & 730 \\
\hline
\end{tabular}

Keterangan:

ar $=$ as received basis

$\mathrm{adb}=$ air dried basis 


\section{Metode Analisis}

Pengukuran dilakukan terhadap kadar air batubara, konduktivitas air umpan boiler, konduktivitas air blow down, konduktivitas air softener, konduktivitas air kondensat, suhu permukaan pipa steam, suhu permukaan saluran gas buang, suhu ruangan mesin kertas, dan emisi gas buang di cerobong boiler. Parameter yang diamati meliputi pengaruh kadar air batubara, rasio udara pembakaran, rasio blowdown, sistem pemulihan kondensat, sistem insulasi, dan kontrol multi boiler terhadap reduksi konsumsi batubara, reduksi $\mathrm{CO}_{2}$, dan reduksi biaya.

Efisiensi termal boiler $\left(\eta_{\text {boiler }}\right)$ dihitung menggunakan metode langsung atau input-output method (Tirumala Srinivas, 2017), yaitu:

$$
\eta_{\text {boiler }}=\frac{\mathrm{F}_{\mathrm{S}} x\left(\Delta \mathrm{H}_{\mathrm{S}}-\Delta \mathrm{H}_{\mathrm{fw}}\right)}{\mathrm{F}_{\mathrm{C}} \times \mathrm{HHV}_{\mathrm{C}}} \times 100 \% \ldots
$$

$\mathrm{F}_{\mathrm{S}} \quad=$ laju produksi steam (ton/tahun)

$\Delta \mathrm{H}_{\mathrm{S}} \quad=$ entalpi spesifik steam $(\mathrm{kcal} / \mathrm{kg})$

$\Delta \mathrm{H}_{\mathrm{fw}}=$ entalpi spesifik air umpan $(\mathrm{kcal} / \mathrm{kg})$

$\mathrm{F}_{\mathrm{C}}=$ laju konsumsi batubara (ton/tahun)

$\mathrm{HHV}_{\mathrm{C}}=$ nilai kalor batubara $(\mathrm{kcal} / \mathrm{kg})$

Nilai kalor tinggi (HHV) dikoreksi terhadap kadar air (MUFG, 2019):

$\mathrm{HHV}_{\mathrm{b}}=\frac{100-\mathrm{b}}{100-\mathrm{a}} \times \mathrm{HHV}_{\mathrm{a}}$

dengan:

$$
\begin{aligned}
\mathrm{HHV}_{\mathrm{a}}= & \mathrm{HHV} \text { batubara dengan kadar air } \\
& \mathrm{a} \%(\mathrm{kcal} / \mathrm{kg}) \\
\mathrm{HHV}_{\mathrm{b}}= & \mathrm{HHV} \text { batubara dengan kadar air } \\
& \mathrm{b} \%(\mathrm{kcal} / \mathrm{kg}) .
\end{aligned}
$$

Nilai kalor rendah (LHV) ditentukan dengan mengurangkan panas penguapan uap air dari nilai kalor tinggi (HHV) (Mahapatra, 2016). Hubungan HHV dan LHV dihitung menggunakan:

$$
\mathrm{LHV}_{\mathrm{a}}=\mathrm{HHV}_{\mathrm{a}}-\left(\lambda_{\mathrm{H}_{2} \mathrm{O}} \times \mathrm{W}_{\mathrm{H}_{2} \mathrm{O}}\right)
$$

dengan:

$\lambda_{\text {H2O }}=$ panas laten air $(\mathrm{kcal} / \mathrm{kg})$

$\mathrm{w}_{\mathrm{H} 2 \mathrm{O}}=$ kandungan air $(\mathrm{kg} / \mathrm{kg})$.
Rasio udara pembakaran $\left(\mathrm{R}_{\mathrm{U}}\right)$ dihitung menggunakan:

$R_{U}=\frac{21}{21-O_{2}}$

dengan:

$\mathrm{O}_{2}=$ konsentrasi oksigen dalam gas buang $(\%)$.

Volume teoritis udara pembakaran $\left(\mathrm{V}_{\text {teoritis }}\right)$ (MUFG, 2019):

$\mathrm{V}_{\text {teoritis }}=8,89 \cdot \frac{C}{100}+26,7 \cdot\left(\frac{H-O / 8}{100}\right)+3,33 \cdot \frac{S}{100} \ldots$.

dengan:

$\mathrm{V}_{\text {teoritis }}=$ volume teoritis udara pembakaran $\left(\mathrm{Nm}^{3} / \mathrm{kg}\right)$

$\mathrm{C}=$ kadar karbon (\%adb)

$\mathrm{H} \quad=$ kadar hidrogen $(\% \mathrm{adb})$

$\mathrm{O} \quad=$ kadar oksigen $(\% \mathrm{adb})$

$\mathrm{S} \quad=$ kadar sulfur $(\% \mathrm{adb})$.

Volume aktual udara pembakaran $\left(\mathrm{V}_{\text {aktua }}\right)(\mathrm{MUFG}$, 2019):

$\mathrm{V}_{\mathrm{aktual}}=\mathrm{V}_{\text {teoritis }} \times R_{U}$

Volume udara berlebih $\left(\mathrm{V}_{\text {excess }}\right)$ :

$\mathrm{V}_{\text {excess }}=\mathrm{V}_{\text {aktual }}-\mathrm{V}_{\text {teoritis }}$

Rugi-rugi panas gas buang $\left(\mathrm{Q}_{\text {loss,FG }}\right)$ :

$$
\begin{array}{r}
\mathrm{Q}_{\text {loss }, \mathrm{FG}}=\left[0,307 \cdot\left(\mathrm{T}_{\mathrm{FG}}-\mathrm{T}_{\mathrm{u}}\right)+\right. \\
\left.2,92 \cdot 10^{-5} \cdot\left(\mathrm{T}_{\mathrm{FG}}{ }^{2}-\mathrm{T}_{\mathrm{U}}{ }^{2}\right)\right] x V_{\text {excess }}
\end{array}
$$

dengan:

$\mathrm{Q}_{\text {lossFG }}=$ rugi-rugi panas gas buang $(\mathrm{kcal} / \mathrm{kg})$

$\mathrm{T}_{\mathrm{FG}} \quad=$ suhu gas buang $\left({ }^{\circ} \mathrm{C}\right)$

$\mathrm{T}_{\mathrm{U}} \quad=$ suhu udara atmosferik $\left({ }^{\circ} \mathrm{C}\right)$.

Rasio rugi-rugi panas (\%) dinyatakan dengan:

$\mathrm{R}_{\text {loss }}=\frac{\mathrm{Q}_{\text {loss }}}{\mathrm{F}_{\mathrm{C}} \times \mathrm{HHV}_{\mathrm{C}}} \times 100 \%$

$\mathrm{R}_{\text {loss }} \quad=$ rasio rugi-rugi panas $(\%)$

$\mathrm{Q}_{\text {loss }}=$ rugi-rugi panas $(\mathrm{kcal} / \mathrm{jam})$. 
Rasio blowdown $\left(\mathrm{R}_{\mathrm{B}}\right.$ ) dihitung menggunakan (MUFG, 2019):

$\mathrm{R}_{\mathrm{B}}=\frac{\mathrm{EC}_{\mathrm{fw}}}{\mathrm{EC}_{\mathrm{b}}} \times 100 \%=\frac{L_{B}}{L_{S}} \times 100 \%$

dengan:

$\mathrm{R}_{\mathrm{B}} \quad=$ rasio blowdown

$\mathrm{EC}_{\mathrm{b}} \quad=$ konduktivitas air blowdown $(\mu \mathrm{S})$

$\mathrm{EC}_{\mathrm{fw}}=$ konduktivitas air umpan $(\mu \mathrm{S})$

$\mathrm{L}_{\mathrm{B}} \quad=$ laju blowdown (ton/jam)

$\mathrm{L}_{\mathrm{S}} \quad=$ laju produksi steam (ton/jam).

Pemulihan air kondensat (CW) dihitung menggunakan (MUFG, 2019):

$\mathrm{CW}=\frac{\mathrm{EC}_{\mathrm{s}}-\mathrm{EC}_{\mathrm{fw}}}{\mathrm{EC}_{\mathrm{s}}-\mathrm{EC}_{\mathrm{c}}} \times 100 \%$

dengan:

$\mathrm{CW}=$ pemulihan air kondensat (\%)

$\mathrm{EC}_{\mathrm{s}}=$ konduktivitas air softner $(\mu \mathrm{S})$

$\mathrm{EC}_{\mathrm{c}}^{\mathrm{s}}=$ konduktivitas air kondensat $(\mu \mathrm{S})$.

Faktor beban boiler (LF) dihitung menggunakan:

$$
\mathrm{LF}=\frac{\mathrm{F}_{\mathrm{S} \text {,actual }}}{\mathrm{F}_{\mathrm{S} \text {, design }}} \times 100 \%
$$

dengan:

$\mathrm{F}_{\text {S,actual }}=$ laju produksi steam aktual (ton/jam)

$\mathrm{F}_{\mathrm{S} \text {,design }}=$ kapasitas boiler sesuai desain (ton/jam).

Reduksi batubara tahunan $\left(\mathrm{A}_{\mathrm{CR}}\right)$, Rasio reduksi batubara $\left(\mathrm{R}_{\mathrm{RB}}\right)$, dan Reduksi biaya $\left(\mathrm{R}_{\mathrm{RP}}\right)$ dihitung menggunakan:

$$
A_{C R}=A_{C C 1}-A_{C C 2}
$$

$R_{R B}=\frac{A_{C R}}{A_{C C 1}}$

$R_{R p}=A_{C R} \times C_{R p}$

dengan:

$\mathrm{A}_{\mathrm{CR}}=$ reduksi batubara tahunan (ton/tahun)

$\mathrm{R}_{\mathrm{RB}}^{\mathrm{CR}}=$ rasio reduksi batubara

$\mathrm{R}_{\mathrm{Rp}} \quad=$ reduksi biaya tahunan ( $\mathrm{Rp} /$ tahun)

$\mathrm{A}_{\mathrm{CC} 1}^{\mathrm{Rp}}=$ konsumsi batubara tahunan sebelum perbaikan (ton/tahun)

$\mathrm{A}_{\mathrm{CC} 2}=$ konsumsi batubara tahunan setelah perbaikan (ton/tahun)

$\mathrm{C}_{\mathrm{Rp}}=$ harga batubara $(\mathrm{Rp} / \mathrm{kg})$.
Reduksi $\mathrm{CO}_{2}\left(\right.$ Reduksi $\left._{\mathrm{CO} 2}\right)$ dihitung menggunakan:

Reduksi $\mathrm{CO}_{2}=\mathrm{A}_{\mathrm{CR}} \times \mathrm{EF}$

dengan:

$\mathrm{EF}=$ faktor emisi $\mathrm{CO}_{2}\left(\mathrm{tCO}_{2} / \mathrm{t}\right)$.

\section{Hasil dan Pembahasan}

Beberapa temuan penting pada saat dilakukan identifikasi co-benefit antara lain penggunaan batubara dengan kadar air tinggi, rasio udara pembakaran tinggi, konduktivitas air umpan dari air sungai tinggi menyebabkan rasio blowdown tinggi, tidak dilakukan insulasi pada mesin produksi yang relatif tua, dan pengoperasian beberapa boiler dengan efisiensi rendah. Efisiensi termal boiler sekitar $66,2 \%$ (berdasarkan nilai HHV batubara), lebih rendah dari kondisi normal yaitu $81-85 \%$ (Barma et al., 2017). Berdasarkan hasil perhitungan, konsumsi energi spesifik sebesar 4,32 ton steam/ton produk atau 11,2 GJ/ ton produk dengan faktor penguapan 4,88 ton steam/ton batubara untuk produksi kertas rokok. Konsumsi energi spesifik dipengaruhi oleh jenis kertas yang diproduksi.

\section{Pengaruh Kadar Air Batubara}

Nilai ukur aktual kadar air batubara pada saat diagnosa adalah $25,8 \%$ dengan nilai kalor $4.101 \mathrm{kcal} / \mathrm{kg}$ dan konsumsi 33.802 ton/tahun. Kadar air batubara biasanya berkisar antara 8 hingga $25 \%$ berat, sedangkan untuk lignit, kadar air bisa mencapai hingga $66 \%$ berat (Xu et al., 2016). Hubungan antara kadar air dan nilai kalor batubara pada pengukuran ini ditampilkan pada Gambar 1.

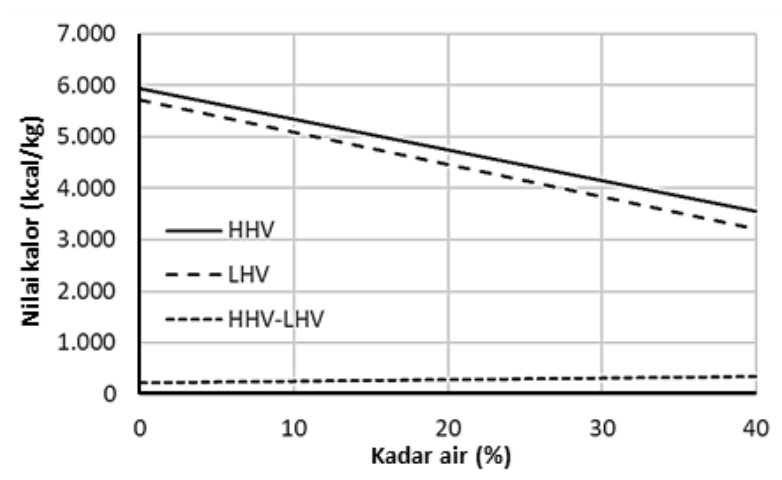

Gambar 1. Hubungan antara Kadar Air dan Nilai Kalor Batubara 
Semakin tinggi kadar air maka semakin rendah nilai kalor batubara karena semakin banyak panas yang dibutuhkan untuk menguapkan air. Selama pembakaran, air yang ada di dalam batubara mengkonsumsi panas sensible dan panas laten untuk menjadi uap panas. Panas yang terserap uap panas ini ikut terbuang bersama dengan gas buang (Liu et al., 2015). Jumlah panas yang diambil oleh uap air berbanding lurus dengan jumlah air yang ada dalam batubara. Efek penurunan kadar air batubara disimulasikan dengan perbandingan kasus bila dilakukan penurunan kadar air dari $25,8 \%$ menjadi $20 \%$ (Gambar 2) dan $10 \%$ (Gambar 3).

Penurunan kadar air menghasilkan reduksi konsumsi batubara dan berdampak pada penurunan biaya dan emisi $\mathrm{CO}_{2}$. Penurunan kadar air dari $25,8 \%$ menjadi $10 \%$ menghasilkan reduksi lebih tinggi dibandingkan penurunan kadar air menjadi 20\%. Semakin rendah kadar air batubara, maka jumlah panas yang dapat digunakan untuk pembangkit steam di boiler menjadi bertambah sehingga efisiensi boiler menjadi naik.

Saat ini, proses pengeringan batubara telah diterapkan secara luas dalam aplikasi batubara lignit untuk pembangkit listrik, seperti pengeringan

\begin{tabular}{l} 
Sebelum \\
$\begin{array}{l}\text { Batubara } \\
\text { Kadar air }=25,8 \% \\
\text { LHV }=4.101 \mathrm{kcal} / \mathrm{kg}\end{array} \rightarrow \begin{array}{l}\text { Sesudah } \\
\text { Batubara } \\
\text { Kadar air }=20,0 \% \\
\text { LHV }=4.464 \mathrm{kcal} / \mathrm{kg}\end{array}$ \\
\hline
\end{tabular}

Rasio reduksi batubara $=8,1 \%$

Reduksi batubara $=2.746$ ton $/$ tahun

Reduksi biaya $=2.004 \times 10^{6} \mathrm{Rp} /$ tahun

Reduksi CO2 $=535 \mathrm{tCO}_{2} /$ tahun

Gambar 2. Kasus bila Kadar Air Batubara diturunkan dari $25,8 \%$ menjadi $20 \%$

\begin{tabular}{l} 
Sebelum \\
$\begin{array}{l}\text { Batubara } \\
\text { Kadar air }=25,8 \% \\
\text { LHV }=4.101 \mathrm{kcal} / \mathrm{kg}\end{array} \rightarrow \begin{array}{l}\text { Batubara } \\
\text { Kadar air }=10,0 \% \\
\text { LHV }=5.089 \mathrm{kcal} / \mathrm{kg}\end{array}$ \\
\hline
\end{tabular}

Rasio reduksi batubara $=19,4 \%$

Reduksi batubara $=6.561$ ton $/$ tahun

Reduksi biaya $=4.789 \times 10^{6} \mathrm{Rp} /$ tahun

Reduksi $\mathrm{CO}_{2}=1.278 \mathrm{tCO}_{2} /$ tahun

Gambar 3. Kasus bila Kadar Air Batubara diturunkan dari $25,8 \%$ menjadi $10 \%$. menggunakan unggun terfluidakan dengan memanfaatkan panas sisa, gas pembakaran, dan steam lewat panas (Xu et al., 2016). Pengurangan kadar air batubara yang lebih ekonomis dan lebih mudah dapat dilakukan dengan cara diangin-anginkan di tempat penyimpanan dalam jangka waktu tertentu. Metode ini sangat tergantung pada kelembaban udara di tempat penyimpanan. Pembelian batubara pada kondisi sudah dihancurkan dapat menurunkan nilai kalor karena meningkatnya kadar air pada waktu penyimpanan dan proses transportasi. Sebaiknya batubara dihancurkan di lokasi pabrik sebelum digunakan untuk menyamakan kadar air dan ukuran partikel batubara.

\section{Perbaikan Rasio Udara Pembakaran}

Pada pembakaran batubara dengan boiler tipe traveling grate, umumnya memerlukan kelebihan udara 30\%-60\% dan konsentrasi oksigen pada gas buang sebesar 5\%-8\%. Hasil pengukuran menunjukkan boiler beroperasi pada rasio udara 2,63 dan konsentrasi oksigen pada gas buang rata-rata $13 \%$. Suhu gas buang pada saat pengukuran adalah $195^{\circ} \mathrm{C}$. Pada keadaan ini terlihat jelas pengoperasian boiler tidak efisien. Udara yang berlebih merupakan salah satu penyebab hilangnya energi pada boiler, karena dapat menurunkan suhu pembakaran, meningkatkan jumlah gas buang yang dihasilkan, dan memperbesar panas yang hilang. Oleh karena itu, optimalisasi udara berlebih dapat secara signifikan meningkatkan efisiensi boiler dan dapat menurunkan emisi gas buang (Ibrahim and Farrukh, 2019). Pada simulasi efek perbaikan konsentrasi oksigen dari $13 \%$ menjadi $8 \%$, dihasilkan reduksi batubara dan penurunan emisi, masing-masing sebesar 5,0\% dan $2.841 \mathrm{tCO}_{2} /$ tahun (Gambar 4).

Alat analisis oksigen online atau sistem trim oksigen perlu dipasang untuk kontrol yang tepat pada kelebihan udara dan kandungan oksigen dalam gas buang. Pengaturan rasio udara pembakaran dapat diatur menggunakan VSD (variable speed drive) (Saidur, Ahamed and Masjuki, 2010). VSD digunakan pada motor kipas untuk mengubah rasio udara pembakaran (Barma et al., 2017).

Selain konsentrasi oksigen, suhu gas buang juga mempengaruhi besarnya panas yang hilang yang berefek pada penurunan efisiensi boiler. Semakin tinggi suhu gas buang maka semakin besar panas yang hilang, berarti semakin rendah 


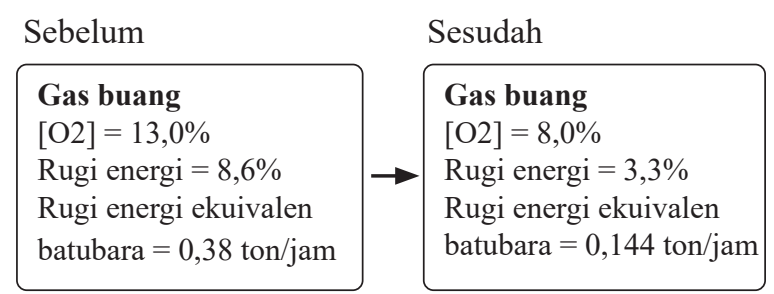

Rasio reduksi batubara $=5,0 \%$

Reduksi batubara $=1.690$ ton/tahun

Reduksi biaya $=1.234 \times 10^{6} \mathrm{Rp} /$ tahun

Reduksi $\mathrm{CO}_{2}=2.841 \mathrm{tCO}_{2} /$ tahun

Gambar 4. Kasus bila Konsentrasi Oksigen Gas buang diturunkan dari 13,3\% menjadi 8,0\%

efisiensi termal boiler. Panas terbuang melalui gas buang merupakan sumber kehilangan panas tertinggi dalam sistem boiler. Pemulihan panas dari gas buang suhu tinggi dapat menghasilkan penghematan energi yang signifikan (Barma et al., 2017).

Tergantung pada suhu gas buang dan konsentrasi oksigen, efek penurunan rugi-rugi panas gas buang dapat diperkirakan dengan membaca Gambar 5. Pada saat suhu gas buang $195^{\circ} \mathrm{C}$ dan konsentrasi oksigen diturunkan dari $13 \%$ menjadi $8 \%$, maka terjadi penurunan rugirugi panas gas buang dari $8,6 \%$ menjadi $3,3 \%$.

\section{Optimalisasi Rasio Blowdown}

Boiler harus menghasilkan steam berkualitas baik dengan stabil dan memasok steam

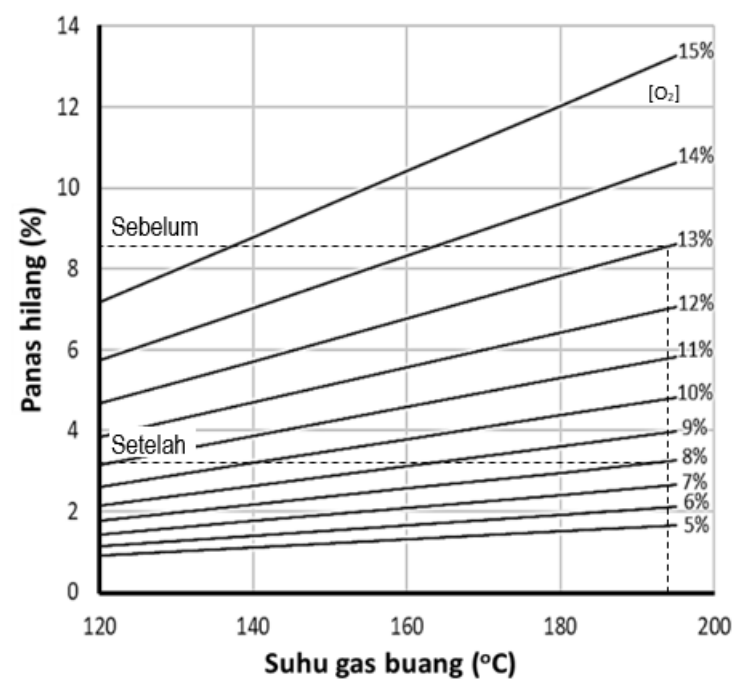

Gambar 5. Pengaruh Konsentrasi $\mathrm{O}_{2}$ dan Suhu Gas Buang terhadap Panas Hilang tersebut secara terus menerus ke mesin kertas yang menggunakan steam. Air umpan boiler mengandung berbagai macam ion seperti kalsium, magnesium dan sebagainya. Jika konsentrasinya tinggi dapat menimbulkan kerak di permukaan dalam pipa dan dapat menurunkan konduktivitas panas pada pipa-pipa alat penukar panas. Untuk alasan ini, air panas di dalam boiler perlu dikuras (blowdown) untuk menjaga konsentrasi ion di dalam air boiler. Jumlah air yang dibuang ini tergantung dari kualitas air yang digunakan boiler. Jika kualitas air baik maka jumlah pembuangan sedikit, namun jika kualitas air jelek maka jumlah pembuangan akan menjadi banyak sehingga jumlah panas yang dibuang bertambah dan membuat efisiensi produksi steam menurun. Kualitas air umpan boiler dapat dievaluasi dari kandungan garam, silika dan sebagainya, tapi dapat juga dievaluasi melalui konduktivitas listrik sebagai salah satu indikator. Jika dilihat dari tingkat konduktivitas listrik, terdapat kasus di mana rasio blowdown lebih dari 5\%. Dari hasil analisis, kondukstivitas air umpan boiler mencapai 217-272 $\mu \mathrm{S}$ dan konduktivitas air blowdown mencapai 2.770-4.840 $\mu \mathrm{S}$ (Tabel 2). Untuk kasus ini, pengoperasian sistem blowdown pada boiler menjadi masalah yang perlu diperbaiki. Air blowdown memiliki suhu tinggi seperti steam yang dihasilkan boiler sehingga jika jumlah blowdown besar, maka efisiensi boiler akan menurun. Rugi-rugi panas blowdown pada umumnya sekitar 1-3\% dari konsumsi bahan bakar (Barma et al., 2017).

Hasil pengukuran selama dua bulan menunjukkan rasio blowdown rata-rata sekitar $11,4 \%$ dengan pengoperasian secara manual. Rasio blowdown ini diukur berdasarkan laju blowdown dan laju steam yang diproduksi. Normalnya, pada boiler dengan pemulihan kondensat mencapai $\geq 80 \%$ akan menghasilkan rasio blowdown sekitar 1,0\%. Evaluasi perbaikan

Tabel 2. Konduktivitas Air Softener, Air Umpan, dan Air Kondensat

\begin{tabular}{lrr}
\hline \multirow{2}{*}{ Sampling point } & \multicolumn{2}{c}{ Konduktivitas $[\mu \mathrm{S}]$} \\
\cline { 2 - 3 } & Pengukuran 1 & Pengukuran 2 \\
\hline Air softener & 578 & 518 \\
Air umpan & 272 & 217 \\
Air blowdown & 4.840 & 2.770 \\
Air kondensat & 17 & 8 \\
\hline
\end{tabular}


Sebelum

\begin{tabular}{|l|l|}
\hline $\begin{array}{l}\text { Air blowdown } \\
\text { Rasio blowdown }=11,4 \% \\
\text { Rugi energi }=3.116 \mathrm{Gcal} / \mathrm{thn} \\
\begin{array}{l}\text { Rugi energi ekuivalen } \\
\text { batubara }=1.241 \text { ton/tahun }\end{array}\end{array} \rightarrow \begin{array}{l}\text { Gas buang } \\
{\left[\mathrm{O}_{2}\right]=8,0 \%} \\
\text { Rugi energi }=3,3 \% \\
\text { Rugi energi ekuivalen } \\
\text { batubara }=0,144 \text { ton/jam }\end{array}$ \\
\hline
\end{tabular}

Rasio reduksi batubara $=5,0 \%$

Reduksi batubara $=1.690$ ton $/$ tahun

Reduksi biaya $=1.234 \times 106 \mathrm{Rp} /$ tahun

Reduksi $\mathrm{CO}_{2}=2.841 \mathrm{tCO}_{2} /$ tahun

Gambar 6. Kasus bila Laju Blowdown diturunkan dari $11,4 \%$ menjadi $1,0 \%$.

dilakukan dengan menurunkan rasio blowdown hingga $1,0 \%$. Hasilnya adalah sebagaimana ditampilkan dalam Gambar 6.

Penurunan rasio blowdown dapat dilakukan dengan pemasangan sistem kontrol blowdown otomatis dan perbaikan kualitas air umpan boiler. Sistem blowdown otomatis dapat dipasang untuk mengontrol laju blowdown, terdiri dari pemantauan konduktivitas secara terus-menerus, dan sistem blowdown otomatis pada level konduktivitas tertentu. Sistem otomatis ini dapat menghemat energi yang terbuang pada sistem blowdown manual.

Besarnya rasio blowdown dapat disebabkan oleh adanya pencemaran pada sumber air yang digunakan untuk bahan baku air industri. Supaya dapat digunakan sebagai air umpan boiler, maka perlu dilakukan perbaikan kualitas dengan cara membuang senyawa ionik yang merupakan sumber pencemaran air. Meskipun metode resin penukar ion untuk produksi air murni untuk boiler banyak digunakan dalam beberapa tahun terakhir, metode membran reverse osmosis cenderung mulai dipilih karena metode resin penukar ion menggunakan bahan kimia berbahaya untuk regenerasi resin digunakan. Pada pengoperasian membran reverse osmosis dengan kapasitas produksi air murni sebesar 14,4 $\mathrm{m}^{3} / \mathrm{jam}$ (berdasarkan kebutuhan air umpan boiler) membutuhkan investasi Rp 3 milyar dengan waktu pengembalian modal selama 12,3 tahun (Tabel 3).

\section{Pemulihan Air Kondensat}

Rasio pemulihan air kondensat rata-rata selama beberapa kali pengukuran berdasarkan analisis konduktivitas air kondensat, air softener dan air umpan yaitu sebesar $43 \%$. Selain memiliki
Tabel 3. Biaya Pengoperasian Membran Reverse Osmosis

\begin{tabular}{lcc}
\hline 1. Biaya peralatan ${ }^{\mathrm{a}}$ : & & \\
\hline - Unit pemurnian air & $1.500 \times 10^{6}$ & $\mathrm{Rp}$ \\
- Peralatan pre-treat- & $1.500 \times 10^{6}$ & $\mathrm{Rp}$ \\
ment & 90 & $\mathrm{kWh} /$ tahun \\
2. Konsumsi listrik & $500 \times 10^{6}$ & $\mathrm{Rp} /$ tahun \\
3. Biaya perawatan ${ }^{\mathrm{b}}$ & 12,3 & tahun \\
Payback period & & \\
"asumsi harga di Jepang; $^{{ }^{6} \text { Perkiraan biaya di Jepang. }}$ & &
\end{tabular}

kandungan panas, kondensat pada dasarnya adalah air distilasi yang ideal untuk digunakan sebagai air umpan boiler. Sistem steam yang efisien akan mengumpulkan kondensat ini dan mengembalikannya ke deaerator, tangki umpan boiler, atau menggunakannya dalam proses lain. Kondensat tidak dikembalikan ke boiler hanya jika terjadi kontaminasi. Meskipun demikian, dimungkinkan untuk mengumpulkan kondensat dan menggunakannya sebagai air proses panas atau melewatkannya melalui penukar panas di mana kandungan panasnya dapat dimanfaatkan kembali.

Efek perbaikan dievaluasi dengan melakukan peningkatan rasio pemulihan air kondensat dari $43 \%$ menjadi $60 \%$. Hasilnya ditampilkan dalam Gambar 7. Simulasi efek peningkatan rasio pemulihan air kondensat menghasilkan reduksi batubara dan penurunan emisi, masing-masing sebesar 1,4\% dan $969 \mathrm{tCO}_{2} /$ tahun.

Penurunan konsumsi batubara ini karena terjadi peningkatan kandungan panas sebesar $1.682 \mathrm{Gcal} /$ tahun yang dapat dimanfaatkan kembali. Selain itu, terjadi peningkatan jumlah air kondensat yang dapat digunakan kembali oleh

\begin{tabular}{|l|l|}
$\begin{array}{l}\text { Air kondensat } \\
\text { Pemulihan }=43 \% \\
\begin{array}{l}\text { Reduksi batubara }=1.229 \\
\text { ton/tahun }\end{array}\end{array}$ & $\begin{array}{l}\text { Air kondensat } \\
\text { Pemulihan }=60 \% \\
\text { Reduksi batubara }=1.714 \\
\text { ton/tahun }\end{array}$ \\
\hline
\end{tabular}

$$
\begin{aligned}
& \text { Rasio reduksi batubara }=1,4 \% \\
& \text { Reduksi batubara }=486 \text { ton/tahun } \\
& \text { Reduksi biaya }=355 \times 10^{6} \mathrm{Rp} / \text { tahun } \\
& \text { Reduksi } \mathrm{CO}_{2}=969 \mathrm{tCO}_{2} / \text { tahun }
\end{aligned}
$$

Gambar 7. Kasus bila Pemulihan Air Kondensat dinaikkan dari $43 \%$ menjadi $60 \%$ 
boiler sebesar 28.038 ton/tahun, sehingga dapat mengurangi kebutuhan air softener.

\section{Pemasangan Insulasi}

Pengamatan menunjukkan beberapa permukaan boiler, pipa steam, pipa kondensat, saluran gas buang, dan ruangan mesin produksi tidak terinsulasi dengan baik. Semua insulasi yang rusak atau aus harus diperbaiki berdasarkan prioritas. Titik panas mengindikasikan terjadinya hilang panas yang berlebihan. Kehilangan panas terjadi karena radiasi, konveksi dan konduksi dari permukaan panas sistem boiler. Jumlah panas yang hilang tergantung pada suhu permukaan panas yang dipengaruhi oleh insulasi (ketebalan, konduktivitas termal, dan kondisi). Untuk meminimalkan kehilangan panas, permukaan panas harus ditutup dengan bahan insulasi yang memiliki ketahanan yang cukup baik terhadap perpindahan panas (Gupta, Ghai and Jain, 2011).

\section{Insulasi Pipa Steam}

Kondisi pipa steam saat ini (termasuk katup, dan lain-lain) dievaluasi jika diinsulasi dengan area target pipa seluas $134,1 \mathrm{~m}^{2}$. Luas permukaan katup, flensa, dan lain-lain dikoreksi dan dikonversi menjadi panjang pipa. Jumlah panas yang dikeluarkan dari perpipaan dihitung dari luas permukaan. Ketebalan dan konduktivitas termal dari bahan insulasi panas dihitung dengan nilai yang diasumsikan. Hasil perhitungan ditampilkan pada Gambar 8.

Simulasi efek pemasangan insulasi pipa steam menghasilkan reduksi batubara dan penurunan emisi, masing-masing sebesar $0,93 \%$ dan $628 \mathrm{tCO}_{2}$ /tahun. Reduksi batubara ini menggambarkan besarnya rugi-rugi panas yang dapat diturunkan dari pemasangan insulasi pada

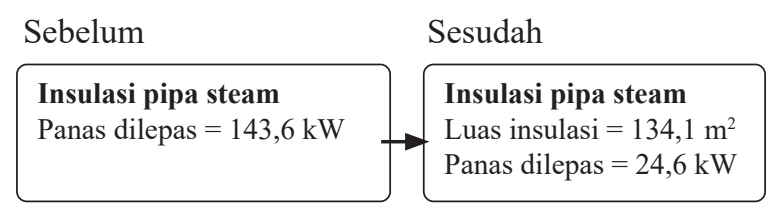

Rasio reduksi batubara $=0,93 \%$

Reduksi batubara $=315$ ton/tahun

Reduksi biaya $=230 \times 10^{6} \mathrm{Rp} /$ tahun

Reduksi $\mathrm{CO}_{2}=628 \mathrm{tCO}_{2} /$ tahun

Gambar 8. Kasus bila Pipa Steam diinsulasi dengan Luas Insulasi $134,1 \mathrm{~m}^{2}$
Tabel 4. Biaya Pemasangan Insulasi Perpipaan Steam

\begin{tabular}{lrl}
\hline $\begin{array}{l}\text { 1. } \\
\text { panas }\end{array}$ & $26.821 \times 10^{3}$ & $\mathrm{Rp}$. \\
\hline $\begin{array}{l}\text { 2. Biaya tenaga kerja } \\
\text { Payback period }\end{array}$ & $18.000 \times 10^{3}$ & $\mathrm{Rp}$. \\
\hline
\end{tabular}

\begin{tabular}{|c|c|}
\hline Sebelum & Sesudah \\
\hline $\begin{array}{l}\text { Insulasi pipa air kondensat } \\
\text { Panas dilepas }=202,9 \mathrm{~kW}\end{array}$ & $\begin{array}{l}\text { Insulasi pipa air } \\
\text { kondensat } \\
\text { Luas insulasi }=263,5 \mathrm{~m}^{2} \\
\text { Panas dilepas }=32,1 \mathrm{~kW}\end{array}$ \\
\hline
\end{tabular}

Rasio reduksi batubara $=1,1 \%$

Reduksi batubara $=387$ ton/tahun

Reduksi biaya $=282 \times 10^{6} \mathrm{Rp} /$ tahun

Reduksi $\mathrm{CO}_{2}=772 \mathrm{tCO}_{2} /$ tahun

Gambar 9. Kasus bila Pipa Pemulihan Air Kondensat diinsulasi dengan Luas Insulasi 263,5 $\mathrm{m}^{2}$

sistem perpipaan steam. Pemasangan insulasi pada perpipaan steam membutuhkan investasi sebesar $\mathrm{Rp} 44,821$ juta dengan waktu pengembalian modal selama 0,2 tahun (Tabel 4).

\section{Insulasi Pipa Pemulihan Air Kondensat}

Kondisi pipa kondensat saat ini (termasuk perpipaan, tangki separator, dan lain-lain) dievaluasi jika diinsulasi dengan area target pipa pemulihan air kondensat seluas $263,5 \mathrm{~m}^{2}$. Hasil perhitungan ditampilkan pada Gambar 9.

Simulasi efek pemasangan insulasi pipa pemulihan air kondensat menghasilkan reduksi batubara dan penurunan emisi, masing-masing sebesar $1,1 \%$ dan $772 \mathrm{tCO} /$ tahun. Reduksi batubara ini menggambarkan besarnya rugi-rugi panas yang dapat diturunkan dari pemasangan insulasi pada sistem perpipaan pemulihan air kondensat. Pemasangan insulasi pada perpipaan pemulihan air kondensat membutuhkan investasi sebesar Rp 101 juta dengan waktu pengembalian modal selama 0,4 tahun (Tabel 5).

Tabel 5. Biaya Pemasangan Insulasi Perpipaan Kondensat

\begin{tabular}{llll}
\hline 1. & Material insulasi panas & $83 \times 10^{6}$ & $\mathrm{Rp}$ \\
\hline 2. Biaya tenaga kerja & $18 \times 10^{6}$ & $\mathrm{Rp}$ \\
Payback period & 0,4 & tahun \\
\hline
\end{tabular}




\section{Insulasi Saluran Gas Buang dan Pemanasan Udara Inlet Boiler}

Suhu gas buang yang keluar dari boiler biasanya berkisar $150^{\circ} \mathrm{C}-250^{\circ} \mathrm{C}$, sekitar $10 \%-30 \%$ energi panas hilang melalui proses tersebut (Barma et al., 2017). Pada suhu seperti itu, gas buang mengandung energi dalam jumlah besar dan menghasilkan efisiensi termal yang relatif rendah (Zaporozhets, 2019). Saat ini, panas dari gas buang digunakan untuk memanaskan air umpan melalui unit economizer dan gas buang diolah dengan mengoperasikan bag filter. Pengoperasian bag filter dilakukan dengan persyaratan suhu gas buang yang diolah tidak melebihi $150^{\circ} \mathrm{C}$. Jika suhu gas buang naik, maka dilakukan proses untuk menurunkan suhu gas buang sehingga terjadi kehilangan panas. Disipasi panas dari saluran gas buang dapat dikontrol dan secara efisien dapat dimanfaatkan untuk pemanasan udara inlet boiler sehingga efisiensi termal boiler dapat ditingkatkan jika dilakukan insulasi saluran gas buang. Penelitian simulasi oleh Ibrahim and Farrukh (2019) menunjukkan pemasangan alat pemanas yang memanaskan campuran udara-bahan bakar sampai $93^{\circ} \mathrm{C}$ dapat meningkatkan efisiensi boiler sebesar $4 \%$.

Evaluasi efek perbaikan bila dilakukan insulasi saluran gas buang dan panas gas buang digunakan untuk pemanasan udara inlet boiler ditampilkan dalam Gambar 10, sedangkan pemanfaatan panas gas buang untuk pemanasan udara inlet boiler ditampilkan dalam Gambar 11.

Pemasangan insulasi dapat menurunkan rugi-rugi panas saluran gas sebesar 73,6 Mcal/jam dan menaikkan suhu gas buang menjadi $206,3^{\circ} \mathrm{C}$. Dampaknya, suhu air umpan keluar dari unit economizer dapat ditingkatkan menjadi $109,7^{\circ} \mathrm{C}$. Gas buang keluar unit economizer pada suhu $141,7^{\circ} \mathrm{C}$ digunakan untuk

\begin{tabular}{ll} 
Sebelum & Sesudah \\
$\begin{array}{l}\text { Insulasi saluran gas buang } \\
\text { Suhu gas buang }=194,5^{\circ} \mathrm{C} \\
\text { Suhu air umpan }=106,0^{\circ} \mathrm{C}\end{array}$ & $\begin{array}{l}\text { Insulasi saluran gas buang } \\
\text { Suhu gas buang }=206,3^{\circ} \mathrm{C} \\
\text { Suhu air umpan }=109,7^{\circ} \mathrm{C}\end{array}$ \\
\hline
\end{tabular}

Rasio reduksi batubara $=2,6 \%$

Reduksi batubara $=865$ ton/tahun

Reduksi biaya $=631 \times 10^{6} \mathrm{Rp} /$ tahun

Reduksi $\mathrm{CO}_{2}=1.726 \mathrm{tCO}_{2}$ /tahun

Gambar 10. Kasus bila Saluran Gas Buang dan Pemanasan Udara Inlet Boiler Diinsulasi

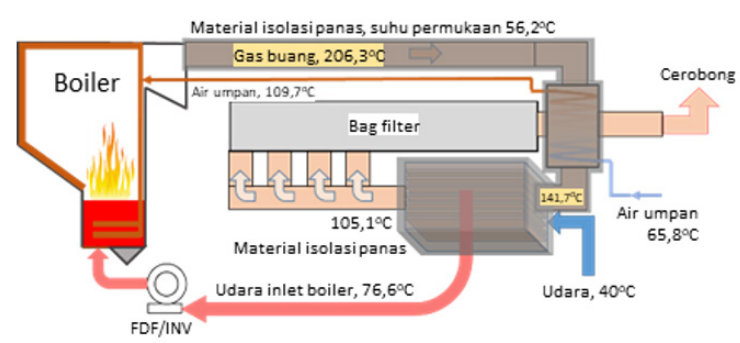

Sumber: Modifikasi gambar dari Laporan Diagnosis Co-benefit Tahun Fiskal 2018 (MUFG, 2019)

Gambar 11. Insulasi Saluran Gas Buang dan Pemanfaatan Panas Gas Buang untuk Pemanasan Udara Inlet Boiler

Tabel 6. Biaya Pemasangan Fasilitas Insulasi Saluran Gas Buang dan Pemanasan Udara Inlet Boiler

\begin{tabular}{lll}
\hline $\begin{array}{l}\text { Biaya pemasangan } \\
\text { fasilitas }\end{array}$ & $2.000 \times 10^{6}$ & $\mathrm{Rp}$ \\
\hline Payback period & 3,2 & tahun \\
\hline
\end{tabular}

pemanasan awal udara inlet boiler dari $40^{\circ} \mathrm{C}$ menjadi $76,6^{\circ} \mathrm{C}$. Total tambahan panas yang dimanfaatkan oleh unit economizer dan unit pemanasan udara yaitu sebesar $3.810 \mathrm{Gcal} /$ tahun atau ekuivalen dengan batubara sebanyak 865 ton/tahun. Simulasi efek pemasangan insulasi saluran gas buang menghasilkan reduksi batubara dan penurunan emisi, masing-masing sebesar $2,6 \%$ dan $1.726 \mathrm{tCO}_{2} /$ tahun.

Pemasangan insulasi pada saluran gas buang dan pemanfaatan panas gas buang untuk pemanasan udara inlet boiler membutuhkan investasi sebesar Rp 2 milyar (asumsi) dengan waktu pengembalian modal selama 3,2 tahun (Tabel 6).

Pemulihan panas gas buang berpotensi menimbulkan korosi karena kondensasi asam. Belerang dalam batubara bereaksi dengan oksigen selamapembakaranmembentukbelerang dioksida, yang bereaksi dengan uap air menghasilkan asam sulfat dalam gas buang. Kondensasi asam terjadi ketika gas buang didinginkan di bawah titik embun asam. Suhu gas buang harus dijaga di atas suhu titik embun asam untuk mencegah kondensasi asam. Jika tidak, sistem pemulihan panas harus dirancang tahan terhadap korosi asam. Jumlah kandungan asam dalam gas buang tergantung kandungan sulfur batubara. Oleh karena itu, suhu gas buang minimum yang diijinkan tergantung pada jenis batubara yang digunakan dalam boiler (Barma et al., 2017). 


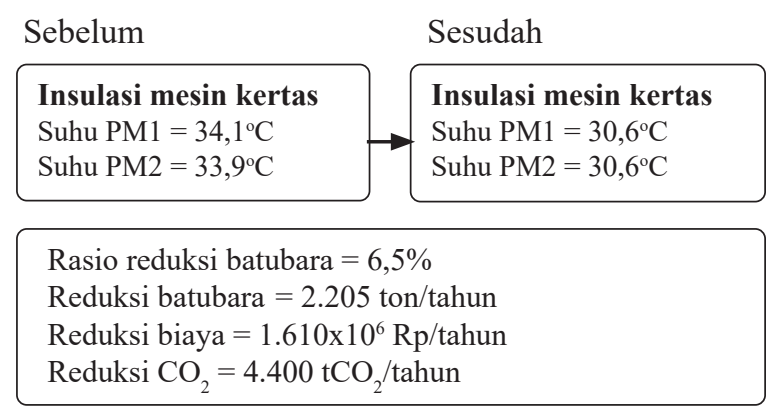

Gambar 12. Kasus bila Mesin-Mesin Kertas diinsulasi

\section{Insulasi Mesin Kertas}

Industri kertas ini memiliki tiga unit fasilitas mesin produksi, Dua unit diantaranya adalah mesin sudah tua dan insulasi tidak dilakukan secara menyeluruh hanya parsial pada bodi dan pipa-pipa steam. Simulasi pemasangan insulasi terhadap kedua mesin tersebutdapat menghasilkan reduksi konsumsi batubara sebagaimana ditampilkan dalam Gambar 12.

Penerapan langkah-langkah insulasi termal dapat mengurangi steam yang dikonsumsi akibat disipasi panas dari mesin, dan sebagai hasilnya, konsumsi batubara menjadi berkurang. Simulasi efek pemasangan insulasi mesin kertas menghasilkan reduksi batubara dan penurunan emisi, masing-masing sebesar $6,5 \%$ dan $4.400 \mathrm{tCO}_{2}$ /tahun. Konstruksi insulasi panas pada dua unit mesin kertas diasumsikan membutuhkan investasi $\mathrm{Rp} 10$ milyar. Waktu yang diperlukan untuk pengembalian modal untuk investasi ini adalah 6 tahun (Tabel 7).

\section{Kontrol Optimum Multi Boiler}

Tabel 8 menunjukkan data produksi steam dari boiler 15 ton/jam dan 20 ton/jam dalam lima hari. Faktor beban masing-masing boiler berkisar 48\%-65\%. Masing-masing boiler beroperasi secara mandiri.

Pengoperasian boiler menyebabkan kehilangan panas yang tetap, seperti panas radiasi dari

Tabel 7. Biaya Pemasangan Insulasi Dua Mesin Kertas

\begin{tabular}{lcl}
\hline $\begin{array}{l}\text { Biaya konstruksi insulasi } \\
\text { panas }\end{array}$ & $10.000 \times 10^{6}$ & $\mathrm{Rp}$ \\
\hline Payback period & 6 & tahun \\
\hline
\end{tabular}

Tabel 8. Data Produksi Steam dalam Lima Hari

\begin{tabular}{|c|c|c|c|c|c|}
\hline \multirow[b]{3}{*}{ Periode } & \multicolumn{5}{|c|}{ Produksi Steam and Faktor Beban (\%) } \\
\hline & \multicolumn{2}{|c|}{15 ton/jam } & \multicolumn{2}{|c|}{20 ton/jam } & \multirow{2}{*}{$\begin{array}{l}\text { Total } \\
\begin{array}{c}\text { Steam } \\
(\mathrm{t})\end{array}\end{array}$} \\
\hline & $\begin{array}{l}\text { Steam } \\
(\mathrm{t})\end{array}$ & $\begin{array}{c}\text { Faktor } \\
\text { beban } \\
(\%)\end{array}$ & $\begin{array}{l}\text { Steam } \\
(\mathrm{t})\end{array}$ & $\begin{array}{c}\text { Faktor } \\
\text { beban } \\
(\%)\end{array}$ & \\
\hline Hari 1 & 7,3 & 48,6 & 9,9 & 49,3 & 17,1 \\
\hline Hari 2 & 8,2 & 54,4 & 12,1 & 60,5 & 20,3 \\
\hline Hari 3 & 8,1 & 53,8 & 12,9 & 64,7 & 21,0 \\
\hline Hari 4 & 7,3 & 48,7 & 12,3 & 61,4 & 19,6 \\
\hline Hari 5 & 7,7 & 51,1 & 10,7 & 53,7 & 18,4 \\
\hline Rata-rata & 7,7 & 51,3 & 11,6 & 57,9 & 19,3 \\
\hline
\end{tabular}

badan boiler. Besarnya kehilangan panas radiasi tergantung pada luas permukaan boiler. Karena boiler memiliki area permukaan yang luas, kehilangan panas akibat radiasi menjadi signifikan saat boiler beroperasi pada beban rendah. Kehilangan panas akibat radiasi dan konveksi pada boiler yang beroperasi pada beban penuh mencapai sekitar 2\% dari total panas hilang (Barma et al., 2017). Karena itu, pengaturan dari besar kecilnya ukuran boiler sangat berpengaruh terhadap efisiensi termal boiler. Jika beberapa boiler dengan kapasitas berbeda dioperasikan, maka konsumsi bahan bakar dapat dikurangi dengan mengoperasikan boiler skala besar pada kondisi optimal dan boiler lainnya yang lebih kecil digunakan untuk mengatasi fluktuasi beban. Berdasarkan karakteristik ini, boiler 20 ton/jam selalu dioperasikan pada sekitar $90 \%$ beban, dan boiler 6 ton/jam dioperasikan untuk mengatasi fluktuasi beban. Efek peningkatan dari pengoperasian boiler seperti ini ditampilkan dalam Gambar 13.

Konsumsi steam sebesar 164.929 ton/tahun dipenuhi dari pengoperasin dua unit boiler, yaitu boiler 20 ton/jam dan boiler 15 ton/jam, masing-masing pada beban rendah. Peningkatan beban boiler 20 ton/jam dari 59\% menjadi $90 \%$ dapat meningkatkan produksi steam menjadi 138.240 ton/tahun dan efisiensi boiler naik menjadi $74,8 \%$. Kekurangan produksi steam sebesar 26.689 ton/tahun dipenuhi dengan mengoperasikan boiler 6 ton/jam pada beban $58 \%$. Pada beban ini, boiler 6 ton/jam memiliki efisiensi $61,1 \%$. Dengan demikian maka boiler 15 ton/jam tidak perlu dioperasikan lagi. Kontrol multi-boiler dengan cara ini dapat menurunkan konsumsi batubara sebesar $8,3 \%$ dan menurunkan emisi $\mathrm{CO}_{2}$ sebesar $4.694 \mathrm{tCO}_{2} /$ tahun. 
Sebelum

\section{Kontrol multi boiler}

Konsumsi batubara $=33.802$ ton/tahun

Konsumsi steam $=164.929$ ton $/$ tahun

Boiler 20 ton/jam:

- Efisiensi termal $=69,8 \%$

- Produksi steam $=89.954$ ton/tahun

- Faktor beban $=59 \%$

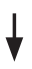

Sesudah

\section{Kontrol multi boiler}

Konsumsi batubara $=31.0089$ ton/tahun

Produksi steam $=164.929$ ton $/$ tahun

Boiler 20 ton/jam:

- Efisiensi termal $=74,8 \%$

- Produksi steam $=138.240$ ton/tahun

- Faktor beban $=90 \%$

Boiler 6 ton/jam:

- Efisiensi termal $=61,1 \%$

- Produksi steam $=26.689$ ton/tahun

- Faktor beban $=58 \%$

Rasio reduksi batubara $=8,3 \%$

Reduksi batubara $=2.793$ ton $/$ tahun

Reduksi biaya $=2.039 \times 10^{6} \mathrm{Rp} /$ tahun

Reduksi $\mathrm{CO}_{2}=4.694 \mathrm{tCO}_{2} /$ tahun

Gambar 13. Kasus bila Boiler 20 Ton Dioperasikan pada 90\% Beban, dan Boiler 6 Ton Dioperasikan untuk mengatasi Fluktuasi Beban
Tabel 9. Biaya Pemasangan Sistem Kontrol Pembakaran Otomatis Boiler 6 Ton

\begin{tabular}{lcl}
\hline $\begin{array}{l}\text { Biaya konstruksi sistem } \\
\text { kontrol pembakaran }\end{array}$ & $2.000 \times 10^{6}$ & $\mathrm{Rp}$ \\
\hline Payback period & 0,98 & tahun \\
\hline
\end{tabular}

Kontrol pembakaran pada boiler 6 ton dilakukan secara otomasi untuk mengatasi fluktuasi beban. Konstruksi sistem kontrol pembakaran otomatis boiler 6 ton diasumsikan membutuhkan investasi Rp 2 milyar. Waktu yang diperlukan untuk pengembalian modal untuk investasi ini adalah 0,98 tahun (Tabel 9).

\section{Potensi Perbaikan Keseluruhan}

Diketahui potensi tindakan perbaikan dengan penyesuaian kadar air batubara, perbaikan rasio udara pembakaran, optimalisasi rasio blowdown, pemulihan air kondensat, pemasangan insulasi, dan kontrol multi-boiler secara teori akan menurunkan konsumsi batubara 16.445 ton/tahun dan menurunkan emisi $\mathrm{CO}_{2}$ sebesar 48,63\%. Selanjutnya hasil perhitungan simulasi efek perbaikan pada tiap tindakan co-benefit diringkas dalam Tabel 10.

Perbaikan-perbaikan ini akan menghasilkan reduksi konsumsi batubara 16.445 ton/ tahun atau $48,63 \%$, dan reduksi $\mathrm{CO}_{2}$ sebesar

Tabel 10. Hasil Perhitungan Simulasi Efek Perbaikan pada Tiap Tindakan Co-Benefit

\begin{tabular}{lcccc}
\hline \multirow{2}{*}{ Tindakan } & $\begin{array}{c}\text { Rasio Reduksi } \\
\text { Batubara }\end{array}$ & Reduksi Batubara & Reduksi $\mathrm{CO}_{2}$ & Reduksi Biaya \\
\cline { 2 - 5 } & $\%$ & ton/tahun & $\mathrm{tCO}_{2} /$ tahun & Rp juta/tahun \\
\hline $\begin{array}{l}\text { Penurunan kadar air } \\
\text { batubara }\end{array}$ & 19,4 & 6.561 & 1.278 & 4.789 \\
$\begin{array}{l}\text { Perbaikan rasio udara } \\
\text { pembakaran }\end{array}$ & 5,0 & 1.690 & 2.841 & 1.234 \\
$\begin{array}{l}\text { Optimalisasi blowdown } \\
\text { Pemulihan kondensat }\end{array}$ & 3,4 & 1.143 & 2.281 & 834 \\
$\begin{array}{l}\text { Insulasi pipa steam } \\
\text { Insulasi pipa pemulihan }\end{array}$ & 1,4 & 486 & 969 & 355 \\
kondensat & 0,93 & 315 & 628 & 230 \\
$\begin{array}{l}\text { Insulasi saluran gas } \\
\text { buang dan pemanasan }\end{array}$ & 1,1 & 387 & 772 & 282 \\
udara inlet boiler & 2,6 & 865 & 1.726 & 631 \\
$\begin{array}{l}\text { Insulasi mesin kertas } \\
\text { Optimalisasi multi boiler }\end{array}$ & 6,5 & & & \\
Total & 8,3 & 2.205 & 4.400 & 1.610 \\
\hline
\end{tabular}


19.377 t- $\mathrm{CO}_{2} /$ tahun. Penghematan biaya yang diperoleh dalam waktu satu tahun diestimasi mencapai Rp 12 milyar.

\section{Kesimpulan}

Kegiatan studi co-benefit peningkatan efisiensi boiler batubara di industri kertas menunjukkan bahwa peningkatan efisiensi boiler ditunjukkan dengan reduksi konsumsi batubara, reduksi emisi $\mathrm{CO}_{2}$, dan reduksi biaya yang sangat signifikan dapat dicapai dengan perbaikan-perbaikan berupa penurunan kadar air batubara, rasio udara pembakaran, optimalisasi rasio blowdown, pemulihan kondensat, insulasi perpipaan, insulasi saluran gas buang, insulasi mesin kertas, dan kontrol beban multi boiler. Perbaikan-perbaikan ini dapat menghasilkan reduksi konsumsi batubara 16.445 ton/tahun atau $48,63 \%$, dan reduksi emisi $\mathrm{CO}_{2}$ sebesar $19.589 \mathrm{tCO}_{2}$ /tahun. Penghematan biaya yang diperoleh dalam waktu satu tahun diestimasi mencapai Rp 12 milyar. Tindakan perbaikan yang paling signifikan pengaruhnya dengan biaya murah yaitu penurunan kadar air batubara, disusul optimalisasi beban multi boiler, dan perbaikan rasio udara pembakaran.

\section{Ucapan Terima Kasih}

Penulis mengucapkan terima kasih kepada manajemen Balai Besar Pulp dan Kertas, Kementerian Lingkungan Hidup dan Kehutanan Indonesia, dan Kementerian Lingkungan Hidup Jepang sebagai penyandang dana "Program Kerjasama Bilateral dengan Indonesia dalam Pengembangan Internasional Teknologi Lingkungan dengan Pendekatan Co-Benefit Tahun Fiskal 2018”.

\section{Daftar Pustaka}

Barma, M. C., Saidur, R., Rahman, S. M. A., Allouhi, A., Akash, B. A. and Sait, S. M. (2017) 'A review on boilers energy use, energy savings, and emissions reductions', Renewable and Sustainable Energy Reviews. Elsevier Ltd, 79(May), pp. 970-983. doi: 10.1016/j.rser.2017.05.187.

Gupta, R., Ghai, S. and Jain, A. (2011) 'Energy Efficiency Improvement Strategies for Industrial Boilers: A Case Study', Journal of Engineering \& Technology, 1(1), p. 52. doi: 10.4103/0976-8580.74541.
Ibrahim, U. and Farrukh, S. (2019) 'Optimization of Fuel in Saturated Steam Boiler through Preheating of Controlled Air-Fuel Mixture', 2019 2nd International Conference on Computing, Mathematics and Engineering Technologies (iCoMET). IEEE, (x), pp. 1-5.

Liu, M., Qin, Y., Yan, H., Han, X. and Chong, D. (2015) 'Energy and water conservation at lignite-fired power plants using drying and water recovery technologies', Energy Conversion and Management. Elsevier Ltd, 105, pp. 118-126. doi: 10.1016/j. enconman.2015.07.069.

Mahapatra, D. (2016) 'A Review on Steam Coal Analysis -Calorific Value', American International Journal of Research in Science, Technology, Engineering \& Mathematics, pp. 143-152.

MUFG (2019) Laporan program tahun fiskal 2018 program kerjasama bilateral dengan Indonesia dalam pengembangan internasional teknologi lingkungan dengan pendekatan co-benefit.

Saidur, R., Ahamed, J. U. and Masjuki, H. H. (2010) 'Energy, exergy and economic analysis of industrial boilers', Energy Policy. Elsevier, 38(5), pp. 2188-2197. doi: 10.1016/j. enpol.2009.11.087.

Song, C., Li, M., Zhang, F., He, Y. L. and Tao, W. Q. (2015) 'A data envelopment analysis for energy efficiency of coal-fired power units in China', Energy Conversion and Management. Elsevier Ltd, 102, pp. 121-130. doi: 10.1016/j. enconman.2014.12.062.

Tirumala Srinivas, G. (2017) 'Efficiency of a Coal Fired Boiler in a Typical Thermal Power Plant', American Journal of Mechanical and Industrial Engineering, 2(1), p. 32. doi: 10.11648/j.ajmie.20170201.15.

Wang, K., Wang, S., Liu, L., Yue, H., Zhang, R. and Tang, X. (2016) 'Environmental cobenefits of energy efficiency improvement in coal-fired power sector: A case study of Henan Province, China', Applied Energy. Elsevier Ltd, 184, pp. 810-819. doi: 10.1016/j. apenergy.2016.06.059.

Xu, C., Xu, G., Zhao, S., Dong, W., Zhou, L. and Yang, Y. (2016) 'A theoretical investigation of energy efficiency improvement by coal pre-drying in coal fired power plants', Energy Conversion and Management. Elsevier Ltd, 122, pp. 580-588. doi: 10.1016/j. enconman.2016.01.048. 
Yang, X. and Teng, F. (2018) 'The air quality cobenefit of coal control strategy in China', Resources, Conservation and Recycling. Elsevier B.V., 129(x), pp. 373-382. doi: 10.1016/j.resconrec.2016.08.011.

Zaporozhets, A. (2019) 'Analysis of control system of fuel combustion in boilers with oxygen sensor', Periodica Polytechnica Mechanical Engineering, 64(4), pp. 241-248. doi: 10.3311/PPme.12572. 
Jurnal Selulosa, Vol. 10, No. 1, Juni 2020:51-64

- Halaman ini sengaja dikosongkan - 